\title{
Affect and Revolution: On Baldwin and Fanon
}

\author{
John E. Drabinski
}

In the remarks that follow, I would like to open up a host of issues raised by reading Frantz Fanon and James Baldwin alongside one another. Fanon and Baldwin are of course two of the most important, and certainly most provocative, writers on questions of race, history, and the future of subjectivity for oppressed peoples. Fanon's eschewing of history in the name of a radically open future sits at the foundation of so much post-colonial thinking. Baldwin's account of the complexities of African-American life under regimes of anti-black racism continues to be crucial for our understanding of cultural formation in the cracks and margins of the lives of the oppressed. The two writers are also very different, and part of my task here consists in elaborating some of those key differences, especially as they arise around the question of memory, history, and cultural formation.

While my remarks here are largely exploratory, I want to establish a set of crucial points and claims. These points and claims center on the affect of shame, which is the common site of affective life under anti-black racist regimes in the work of Fanon and Baldwin. For both Fanon and Baldwin, the legacy of anti-black racism lies in its production of shame as an atmospheric affect - an affect that is not one among others, but rather a mood within which all other affects, values, and aspirations are staged and framed. In that sense, shame is a mood that forms, and is therefore a constitutive component of, most (if not all) affects in black subjectivity. And so, for 
Fanon and Baldwin, shame is a critical site of analysis as both diagnosis (we must understand the affective life produced by anti-black racism and how deeply it is written into the psyche) and transformative resistance (the confrontation with shame is a moment of transforming subjectivity and the future, as well as, for Baldwin, a moment of retrieval of forgotten elements of black history). Differences between Fanon and Baldwin emerge here, and one of the threads that guides the following reflections is an interpretation of Fanon's Sartreanism-the break with history, the purity of the future, the abjection of memory - that identifies important limits to his legacy. Whatever his ecstatic visions of the future, Fanon insists throughout his work that the past is abject and only a future that says yes to another world by simultaneously saying no to history is a future worthy of revolution. Black subjectivity retains its freedom, for Fanon, even when that freedom cannot be drawn from cultural forms - an important claim given his characterization of so many black cultural forms as colonized or too tainted by history's pain (his dismissal of blues, jazz, and creole languages come to mind). It is precisely around that question of the status of cultural forms under anti-black racist regimes that Baldwin breaks from Fanon. Whereas jazz and blues remain largely expressions of abjection for Fanon in Black Skin, White Masks, Baldwin sees in the same expressions of cultural resistance, uniqueness, meaning, and, in a word, life. This simple split regarding the status of cultural production is returned to history and memory as the difference between Fanon and Baldwin on the question of what the past offers to the revolutionary black subject.

I say all of this because it is one of the key threads and interpretative suppositions across the present reflections. In all, the arc of what follows consists of tracing out this basic claim: for Fanon and Baldwin, liberation from anti-black racism is tantamount to revolution against the affect of shame. Struggle against shame is no small matter and requires a subtle, nuanced 
account of the scope and reach of anti-black racism. Anti-black racism is a total projectwhether that project is manifest in the plantation, colonial relations, or the simple violent hostility of the (white) society in which black subjects live. Internalization of feelings of inferiority and shame manifests the total project in the heart of the psyche. And yet revolution is always still possible; resistance to shame, and therefore the promise of transformative action and re-formation of subjectivity, remains possible, if exceptionally difficult work. The terms of that work, and what it can draw on from the past, form an important difference between Fanon and Baldwin, as well as the conditions of any theory of liberation.

There are three parts to my reflections here. In the first section, I treat the theme of shame in Fanon and Baldwin, with particular attention to Black Skin, White Masks and The Fire Next Time. Both of those works understand shame as the effect of anti-black racism and locate the affective life and after-effects of shame in the center of subjectivity. As well, for both, shame is such a powerful affect because it reflects the aspiration of anti-black racism (colonialism in Fanon, segregation and violence in Baldwin) to be a total project, capable of disabling black subjects at the core of conscious life. While there are limits to such aspirations, anti-black racism remains a force of total transformation; what it requires to move outside of shame, then beyond it, is a change of the most exceptional and remarkable character, even in its everydayness. The second section of this paper raises this issue of moving outside, then beyond, shame in the context of the question of home. What is home? And how is the affective life of home framed by the force of shame and its overcoming? The third and final section raises the issue of transformation most directly by reintroducing the meaning of revolution. For both Fanon and Baldwin, liberation from shame and its long shadow is a revolutionary act, one that uproots the totality of the racist lifeworld in order to make another subjectivity possible. Home, that site of 
both violence (racism's reach as a total project) and fragments of resistance (survival and cultural formation on the margins of racist regimes), names a point of both convergence and divergence. For both, the question of home is paramount in anti-racist struggle, and yet, as we will see, Fanon's eschewing of history and memory contrasts with Baldwin's retrieval of the cultural complexity of resistance in ways that are absolutely decisive for theorizing shame as the affective site of oppression and liberation.

In all, this comparative study of Fanon and Baldwin underscores a crucial question in theorizing liberation: what is the meaning of the past, and how does that meaning inform the imagined future? The temporality of liberation—revolution, really—departs from the present and from a diagnosis of the affective core of racial oppression as shame. The scope of anti-black racism is here articulated from the center of subjective life, where the total project of persecution comes to live in the psychic life of the body. What remains for meaning making in the midst of that persecution? For Fanon, nothing much worth retaining. For Baldwin, there is so much that remains. In that difference, which is also a difference concerning the meaning of home and the geography of thinking, we get some clarity on this critical question: in our imagination of the future, what and who is history to us? And what and who are we from history? And, in the end, what sort of revolutionary action is necessary to say yes to life, place, and home, and what sorts of affects both motivate action and emerge in another future?

\section{Race and Shame}

Who are they, in truth, those creatures, who hide, who are hidden by social truth beneath the attributes of bicot, bounioule, arabe, raton, sidi, mon z'ami? (Fanon, "The 'North African Syndrome"” 3-4) 
Fanon's Black Skin, White Masks (1952) remains his most incisive, detailed exploration of the meaning and structure of anti-black racism, in particular how racism transforms the affective life of black subjectivity. Affective life arises in the space between the gaze and the black body. The book owes no small debt to Sartre's work on anti-Semitism in Anti-Semite and Jew, published less than a decade prior, but also develops a position through a deep conversation with the Négritude movement. A note on both to begin.

Black Skin, White Masks begins with an existential-phenomenological schema that readers of Sartre surely find familiar. Subjectivity and embodiment function as inseparable. The subject is not disembodied consciousness, but instead an incarnate being who lives in the world as a social being through and through. The distinction between being and the social collapses at the moment of the genesis of subjectivity; consciousness emerges out of traffic through the world, and the subject sits between the space of being in the world and the capacity to resist from outside that world. So, for Fanon, and we here see his very mid-1950s existentialist startingpoint, we cannot say that the body makes subjectivity from the exterior, nor that the subject simply animates the body from the inside. Rather, the embodiment of the subject lies in its presence to and presencing in the world. As such, the incarnate subject moves to assert that presence in the world, to articulate an identity to a world that is far from indifferent, while at the same time understanding that the struggle for the articulation of identity is initiated by the subject's fundamental worldliness. Affective life is central to this starting-point. The forms of alienation peculiar to the colonized (in Black Skin, White Masks, it is the West Indian experience of colonization in particular) structure the experience of knowing and being-a sort of racialization, we might say, of Heidegger's founding insights into mood and being in Being and Time. ${ }^{1}$ The racialization of mood, and so the kinds of anxiety and ontological insecurity that 
emerge from that racial experience, inserts the incarnate subject in the history of a place: to be is to be embodied, and the racialized context of the colonial body introduces specific, nongeneralizable affects that create very particular experiences of knowing and being.

Anti-black racism functions insofar as it draws on the social, cultural, and historical abjection of the black body. Abjection is not just a social relation, however. Rather, it is a social relation and an ontology of the subject at one and the same time, and so Fanon will look not just to cultural and political forces as sites of diagnosis, but also (and even foremost) to the most intimate sites of subjective life. Abjection of the body in the social relation produces a subject fundamentally structured by shame: a sense of disgrace and disrepute at the heart of identity. I introduce this term here in order to gather together a cluster of Fanonian motifs and pathological names, as well as to underscore the moral psychology of anti-black racism. Judgment is made interior to the subject. Interiority accomplishes the administrative function of external relationssocial, cultural, and political constraints—with efficiency and cruelty. Shame disables the subject through a sense of inferiority, precarity, and, perhaps most importantly, the elimination of an enabling memory and history. History and memory are histories and memories of shamefulness - something of which, I would argue, Fanon does not quite shake free-and therefore bequeath to the subject the condition of shame and abjection from the inside out, which is only deepened by the affirmation of such a condition in a racist world. History and memory therefore function with special power in the colonial relation. With institutions of the colonizer in place, all of which work as Althusserian ideological state apparatuses ${ }^{2}$ (constructing identity, reproducing cultural forms and values), the abjection of memory and history deepens and solidifies the abjection of the body. There is no noble memory and history and sense of 
resistance, but only a story of defeat and subjugation. The body bears this story on the skin, which then becomes the fundamental affective structure of the psyche.

So located, the affect of shame functions very much like Sartrean guilt (the irreducible consequence of our absolute freedom) — namely, as a condition before action that then animates the meaning and significance of any action whatsoever. Shame and identity intertwine at every level of subjective life. Fanon therefore locates the problem of shame and identity in the most intimate, yet also expansive place: language. Language is of course not merely an instrument, nor is it an abstract structure with a distant history from consciousness and world. Language sets the very terms of relation to self and world. "To speak," Fanon writes in a well-known passage of Black Skin, White Masks, "means being able to use a certain syntax and possessing the morphology of such and such a language, but it means above all assuming a culture and bearing the weight of a civilization" (1-2). There is no place for black subjects in colonial culture, except as derivative beings or subjectivities carrying a decisive asterisk with their identity—French, yes, but French and black. And yet there is the compulsion to speak French and, further, to perfect that French in two senses: exclusive language of transaction (marginalize or eliminate Creole and pidgins) and refining the art of diction. "At school," Fanon writes

the young Martinican is taught to treat the dialect with contempt. Avoid Creolisms. Some families forbid speaking Creole at home, and mothers call their children little ragamuffins for using it ... Yes, I must watch my diction because that's how they'll judge me. He can't even speak French properly, they'll say with the utmost contempt. (Black Skin 4)

Contempt undermines the black subject from the outside, which, in the cruel efficiency of the affect of shame, then regulates and subjugates the subject from the interior. That is, the black subject is denied access to her own language-let us not forget that Creoles and pidgins are fully coherent languages, with names for the world and idiomatic complexity, play, and creativity- 
and returned to the colonizer's language in which she has no real place. This is fundamentally a movement of loss, and shame is the affective structure that both motivates the movement away from Creole and is the result of the retreat to the colonized space of the black French speaker.

If language carries culture, and culture imports a system of values and valuation into the psyche, then we should not be surprised when Fanon's analysis turns to the moral dimension of alienation. Alienation conditions the movement away from Creole to French, which means here that the subject is split in the heart of its identity. Fanon writes:

Moral consciousness implies a kind of split, a fracture of consciousness between a dark and a light side. Moral standards require the black, the dark, and the black man to be eliminated from this consciousness. A black man, therefore, is constantly struggling against his own image. (Black Skin 170)

Here is the birth of what Fanon calls the inferiority complex. Colonialism, for Fanon, is a Manichean system - a claim that moves to the center of the analysis in Wretched of the Earthand this system of difference is always more than an imposition by physical or political force. Were colonizer-colonized relations reducible to physical and political force, decolonization would be accomplished at the very moment in which the colonizer leaves colonized land. Inferiority is a complex because it takes place in the psyche. If language alienates in the colonial relation, and language is situated at the foundations of thinking and being, then the event of language is the event of the coming into being of the psyche. Thus, colonialism wounds from the very outset. To be colonized is to be wounded. The wound does its work in the affective structures that structure relations to thinking, being, embodiment, identity, and so on. In other words, colonization is a total project.

The wound is therefore not just a wound of difference; this is not simply a matter of epistemological confusion and disorientation. The wound is also, even firstly, moral. Moral, that 
is, in the sense of determining from the outset what is possible in terms of good and bad (or even evil), but also in terms of the long tale of value that attends to the language of race in anti-black racist regimes. Morality and ontology intersect at the origin-point of the psyche. Black subjectivity is morally complicated from the outset, and the social, cultural, and political structures of subjugation and marginalization confirm and reproduce that wounded identity at every turn. A total project. And yet subjectivity is also a site of resistance. Hope is neither simple nor straightforward, but is nevertheless possible. Fanon therefore identifies struggle at the heart of consciousness, but we cannot articulate that struggle in generalizable terms. For, to be sure, subjectivity is always a struggle with itself - the struggle to be moral, present, just, knowing, and so on, all in the face of the anonymity of being and modern life. Indeed, Hegel, to whom Fanon owes so much as a theorist, demonstrated this in world-historical terms in Phenomenology of Spirit. So, in a certain sense, one can see a generalized existential position emerge at this moment. Fanon's black subject does not struggle against the world or against competing desires, impulses, and energies within conscience and consciousness, but rather struggles against the image of himself. The inferiority complex installs a measure in the psyche against which the black subject will always fall short-morally, and so, ontologically, his being in and of the world. Language and the imagination are inseparable. In this context, Fanon describes, across his work, how such inseparability stalls black subjectivity inside the psyche itself, before the subject engages with and resists the world, and thus internalizes the subjugating dynamics of colonialism as a precondition of being a being in the world. This is dense and dispiriting stuff, and yet it follows directly from the opening claim of Black Skin, White Masks that language is how one inhabits the world. The colonizer's language is the condition for the possibility of habitation. We set up our home - the psyche - in language. In that home, in that language, an image is produced 
in the racist imaginary that wounds or amputates black subjectivity at the heart of what it means to be.

We can see quite easily how Baldwin's work takes up the very same sorts of issues, in particular the affective structure of an internalized anti-black racism. To be sure, he works in the context of the United States, and so not, strictly speaking, in colonial terms. And yet anti-black racism functions affectively in the same terms, installing a set of complexes that, just as much as external legal and political structures, set the terms of black liberation.

Baldwin's long essay The Fire Next Time is probably his best-known work, and for good reason. The essay begins where the early Baldwin so often begins: the travails of childhood, the cruelty of poverty and violence, and the damaging illusions of comfort and liberation. Poverty and violence do double work. On the one hand, they produce structures of subjugation that reproduce themselves through the repressive state apparatus. Racism functions as an external practice of aggression and harm. On the other hand, and here Baldwin echoes Fanon's foundational insights, poverty and violence reproduce the basic ideological structure of racism: inferiority. Remembrances of Harlem, from his earliest essays onward, come back to this theme time and again. What lines of flight from inferiority are possible? The church is never enough, the Nation of Islam is always too much, and Baldwin is instead left with the existential condition of black life. He writes:

In the same way that we, for white people, were the descendants of Ham, and were cursed forever, white people were, for us, the descendants of Cain. And the passion with which we loved the Lord was a measure of how deeply we feared and distrusted and, in the end, hated almost all strangers, always, and avoided and despised ourselves. (Baldwin, The Fire Next Time 40-41)

Religion provides comfort, paradoxically, by affirming the very terms of inferiority, but with the twist that Christianity can always provide: the meek are the chosen and most beloved by God. 
But here Baldwin addresses the cruel side of this: to love God in this way is to say yes to selfhatred.

In The Fire Next Time, Baldwin turns from Christianity and the black church's (perhaps unwitting) affirmation of the affect of inferiority to the opposing cultural force of the mid-1960s, the Nation of Islam and its emphasis on black superiority. But that turn does not remedy the pathology identified as the interiorization of anti-black ideology. Rather, to put it in Fanon's terms, the Nation's reversal of racist terms only confirms the terms of anti-black racism by reifying, in the black power gesture of superiority, the Manichean structure of raciological thinking. That is, the Nation merely reverses the terms of inferiority. While this surely labors against the affective elements of the inferiority complex and, in perhaps the best feature of black nationalism, promises to challenge the ideologically-laden structures of poverty and violence (through community revitalization and focus), ${ }^{3}$ the Manichean structure of social relations remain intact. The critique is for Baldwin not radical enough. Radical critique, which uproots the affective structures that issue from racism and raciological thinking, reconfigures the social forces of race and relation.

Radical critique of course requires a proper understanding of the terms of harm. Baldwin, like Fanon, begins with the existential situatedness of the subject. That situatedness produces the inferiority complex or what Baldwin calls self-hatred. The interiority of self-hatred is a symptom of the existential condition of irreducible non-belonging. Baldwin writes:

The universe, which is not merely the stars and the moon and the planets, flowers, grass, and trees, but other people, has evolved no terms for your existence, has made no room for you, and if love will not swing wide the gates, no other power will or can. (The Fire Next Time 30) 
This passage points us in two directions: the diagnosis of the terms of alienation and the metaphysics of cure. We must of course postpone the latter until the closing section of the present work, but the terms of alienation are set out by Baldwin in the very same terms we find in Fanon. Has the world evolved terms for black existence? This question evokes Fanon's reflection on moral consciousness, where he notes, like the Négritude thinkers before him, that blackness is fated to abjection in the world. In "Everybody's Protest Novel," Baldwin writes:

It is the peculiar triumph of society - and its loss - that it is able to convince those people to whom it has given inferior status of the reality of this decree; it has the force and the weapons to translate its dictum into fact, so that the allegedly inferior are actually made so ... [W] find ourselves bound, first without, then within, by the nature of our categorization. ("Everybody's Protest Novel" 32)

The difficulty here is the contingent character of the interior life of subjectivity. One does not live in a disembodied consciousness. One lives in a world with others, so if that world, those others, populate the lifeworld with terms incompatible with certain forms of incarnate being, then the consciousness returned to the black subject is alienated from its origins and from the interior. The stakes could not be higher: the interiorization of anti-black racism and the affect of shame - the sense that existence itself is a humiliation and indignity — means the inability to say yes to life. It is not that the black subject says no to life in Baldwin's text, but rather that to be is itself the incapacity to affirm being. "For black is the color of evil," Baldwin writes, "only the robes of the saved are white. It is this cry, implacable on the air and in the skull, that he must live with” (“Everybody’s Protest Novel” 32-33).

If blackness has no place in the world, and the world generates only the affective structures of shame, guilt, and self-hatred, then what are we to make of place? Is there a sense of home for black subjectivity? What sorts of revolutionary acts and transformations are necessary for home and place to emerge? 


\section{The Ambivalence of Home}

SECOND THESIS-That the attitude of medical personnel is very often an a priori attitude. The North African does not come with a substratum common to his race, but on a foundation built by the European. In other words, the North African, spontaneously, by the very act of appearing on the scene, enters into a pre-existing framework. (Fanon, "The 'North African Syndrome,"” 7)

If alienation and shame express the relation of black people to the world in an anti-black racist world, then the question arises quite naturally: how is one to address this alienation and shame? How can the harm be reversed? And, therefore, how can the legacy of harm be transformed into something productive? In other words: what is the future?

Were the problem simply the interiority of the psyche, one could imagine self-help and self-affirmation as the alpha and omega of transformation. But Fanon and Baldwin begin in that difficult space of the existential subject. One comes into being in and of the world, so the transformation called for in anti-racist struggle is a total project. The project, in the end, is oriented toward finding that place in the world unbound by the racial categories of history, a place with terms and room for existence.

Thus, we arrive at the question of home. Home is a question that for both Fanon and Baldwin is enmeshed in affective life and possible only after a transformation of the dynamics of the interiorization of anti-black racism. That is, home is comprised of a precarious and perhaps impossible set of historical experiences - not by roots or legacy (the Middle Passage and the plantation wreck those relationships), but rather in and through the experience of loss, alienation, and the emerging struggle of the movement against anti-black racism. Home is therefore not a settled place. To be at home is paradoxically, perhaps, to be either not at home or in the between space of making place. In The Fire Next Time, we see this most clearly in Baldwin's treatment of what we might call his two temptations: Christianity and black nationalism. The church, as we 
have seen, does not settle accounts and cannot establish place. Otherworldliness tempts because it posits a line of flight from the world. Who would not want to escape a world that offers nothing but hostility and persecution? Baldwin rejects this line of flight on Nietzschean grounds. Christianity cannot address the existential condition of black subjectivity precisely because it does not express rage - a revolutionary affect —against shame and the inferiority complex, but instead only sees a kind of universality of that shame and inferiority: the sinful nature of the human.

Sin is a powerful characterization of the human. As Nietzsche has shown in such provocative fashion, the appeal to sinful nature denies the value of life itself. If life is denied as a value, then suffering in the world is not a spur to rage, but instead a constant reminder of the ultimate value and desirability of death. At the same time, the Christian account of sin gives Baldwin a preliminary language for how to conceive home in a world that offers hostility and persecution. Sin is a name for being out of place and unreconciled to the world as a foundation of being, rather than a loss of place after. Perhaps, in a secular reappropriation of Christianity's terms, we can conceive the problem of home as sites of tension and world-making, rather than sites of comfort and belonging. Baldwin writes in The Fire Next Time: "I knew the tension in me between love and power, between pain and rage, and the curious, the grinding way I remained extended between these poles - perpetually attempting to choose the better rather than the worse" (60). This tension is the dynamic of becoming. In a sense, this is the becoming of subjectivity as such - the relation of self to world is always a negotiation and an extension of the subject beyond its grasp and control. At the same time, the condition and situation of black subjectivity fundamentally alters the ecstatic structure of affective life precisely because the meaning of home is at stake. To wit: if we presume a sense of belonging, then the tension of 
subjectivity in ecstatic affective life is initiated by the loss of or threat to a sense of home. However, if we begin with the alienation produced by anti-black racism, then ecstatic affective life, as its originary condition, is suspended between the reactive structure of rage and pain - the fundamental objection to persecution and hatred-and the aspirational structure of a wanting to belong and desiring a place. Baldwin is always careful to prescribe this wanting and desire without an appeal to white ideality; this is the strength of his theoretical work, without a doubt, and a large part of its complexity.

Just a handful of years earlier, Baldwin evoked the simultaneity of pain and home in his essay "Princes and Powers." Set between two poles, how could a place that has meant unprecedented mass-displacement and cruelty be called home? "Princes and Powers" asks this question in response to the 1956 Negro Writers and Artists Congress in Paris, a gathering at which the leading exponents of Négritude spoke and attempted to give context and justification to the emerging, new version of a Pan-Africanist vision. The Négritude writers can be read in the present context as theorists of homelessness. If the slave trade and colonialism decimated black people, and that decimation is all across the board (language, culture, religion, the arts and sciences - and yet resistance is always possible, if exceptional), then it raises the question of the meaning of diaspora. Is diaspora simply a geographical note in a terrifying history? That is, are black people bound to Africa as a line on a map is bound to its point of origin, which, in this case, would mean that black people share a general geographic place of origin and nothing more? Or is diaspora a name for something deeper, an (albeit suppressed and nearly annihilated) alternative life philosophy ${ }^{4}$ that could serve as the foundation for black identity? The Négritude movement articulates and defends a robust version of the latter. For thinkers like Aimé Césaire and Leopold Senghor, the primary intellectual architects of Négritude, diaspora comes to mean 
that black people are fundamentally lost and set astray in the post-colonial, post-slave trade world. Lost, but not without the possibility of retrieval. Retrieval is largely a cultural movement - a feature that distinguishes Négritude from many versions of black nationalism from Martin Delany and Marcus Garvey and forward-and so not a project of physical relocation. Black culture is lost in the domination of the white world and has no real hope for a place in the wake of that domination. Fanon draws on so much of this diagnosis in Black Skin, White Masks, especially in his phenomenological analysis of diction and alienation. Baldwin, in "Princes and Powers," sees the very same sorts of things in Négritude: an irrefutable diagnosis of the experience of blackness in an anti-black racist world, the rage and grievance leveled against those who have cause unspeakable pain, and a sense of shared identity in this shared experience, rage, and grievance. But, like Fanon, Baldwin does not ultimately appeal to the cultural subconscious of an Africanist life philosophy; black culture, and so a sense of connection and fecund relation that would generate the feeling and meaning of home, cannot (and even should not) be revitalized by its re-Africanization. What remains after so much pain and suffering, if retrievable traces of Africa are lost in the centuries of the plantation, then colonialism? How can the Americas be anything other than sites of abject suffering?

It is important here to underscore the relationship between home and memory. The relation between home and memory is the common thread across the variety of Négritude positions developed at the 1956 conference, as well as, perhaps surprisingly, the basis of Baldwin's own rejection of the Négritude theorists. The present is untenable. The untenable character of the present forges a common identity among black subjects, all of whom know the experience of and affectively relate to the rage and grievance that motivates the Négritude movement, Fanon's existentialism, Baldwin's own peculiar version of the same, and indeed any 
black liberation movement whatsoever. This means that the future emerges as the problem for thinking. But the future cannot be thought without an engagement with the past, whether that is an engagement that retrieves or an engagement that destroys history in its spiritual forms. If, for Négritude, thinking the future is a kind of memory project, a particular retrieval of the spirit of a past crushed and suppressed under regimes of domination, then we can say that the future is a felt aesthetic imagination that draws on the felt aesthetic past. Négritude wants inspiration-to breathe life into a withering diaspora. Thus, Césaire and Senghor, characterized with their wellknown hyper-masculinity, famously infuse their poetry with images of a new virility and life impulse that both transforms the untenable present into a livable future and calls upon a past purged of pain and loss, rehabilitated as a forgotten-now remembered-force of life and reproductive capacity. Memory connects to two possibilities. First: the connection to the immediate past as the material subjugation of black bodies connects to impotence, despair, and hopelessness. This is the past as the present. Second: the connection to the past as a spiritual life force connects to a retrievable life philosophy that makes another, altogether virile and potent future imaginable. This is the past as the future. Strange temporalities indeed, and yet the world after catastrophe always calls for new conceptions of time, memory, and creation. Catastrophe, after all, does its most cruel work in the disabling of the past as a resource for the future, which, in turn, creates conditions of cultural dependency and persistent alienation for the colonized. For Négritude, the suppressed, but never fully murdered, life philosophy of African "civilization"which Césaire famously distinguished from "culture" at the 1956 conference, marking civilization as the foundation of tradition before and after colonialism-undermines the conditions of spiritual death. The future need not despair. 
Baldwin of course rejects this story of diaspora and, in fact, in "Princes and Powers" he might be read as rejecting the notion of diaspora as such. In general, Baldwin's review of the 1956 conference contemplates the intersection of the familiar and the strange amongst the conference participants, noting varieties of shared experience, but much more underscoring points of difference. Notes of shared experience echo Baldwin's famous remark in “Everybody's Protest Novel" that Bigger Thomas-Richard Wright's central character in Native Son-lives in the minds of all black people, no matter the critiques one might have of certain forms and expressions of moral outrage. And yet there are the key points of difference in the experience of blackness concerning the relationship between pain and home. Whereas the pain of history compels Négritude toward another past, a past animated by an Africanized vitalism that saturates aesthetic sensibilities, Baldwin is moved to another reckoning with the past. Just as he had argued in "Everybody's Protest Novel" that Wright misunderstands the formation of folkways and traditions out of the terror of anti-black racism, Baldwin revisits the idea of land, home, and relation in the United States, wondering if in fact the Négritude writers, with their memory project of life philosophy and its essential blackness, are capable of thinking the experience of home in the Americas.

To begin, Baldwin places black people at the heart of the logic of home-making in the United States, rather than placing black people, as Fanon does, outside the national and cultural rhetoric of colonial identity. Whereas for Fanon the black subject is lost in the colonizer's world - disoriented by the weight of a total project of domination-Baldwin claims an interdependency of white Americans on black abjections that exceeds Fanon's (and Césaire's) claim that the colonizer is also harmed by colonialism. In that interdependency, and even in the swirl of abjection and violence, there is possibility and meaningful cultural formation- 
something Fanon does not contemplate, and even dismisses in his treatment of Creole, jazz, blues, and other aesthetics cultural productions in Black Skin, White Masks. "It was a society," Baldwin writes of the United States, "in which nothing was fixed and we had therefore been born to a greater number of possibilities, wretched as these possibilities seemed at the instant of our birth." ("Princes and Powers," 45) Birth and possibility—this pairing changes the meaning of exile and descendants, infusing a sense of home into (and even against) any notion of diasporic identity. Baldwin writes further:

Moreover, the land of our forefathers' exile had been made, by that travail, our home. It may have been the popular impulse to keep us at the bottom of the perpetually shifting and bewildered populace; but we were, on the other hand, almost personally indispensable to each of them, simply because, without us, they could never have been certain, in such a confusion, where the bottom was; and nothing, in any case, could take away our title to the land which we, too, had purchased with our blood. ("Princes and Powers" 45)

Baldwin does two interesting things in this passage. First, he invokes the very terms that provoke Fanon to reject history and its possibilities: wretched possibilities. Second, with the notion of land, coupled to the suffering and struggle named by purchased, Baldwin simply asserts home. Wretched possibilities produce alienation, to be sure, but in this interestingly transformed language of sin - the Americas are not pure, pain and rage are intertwined like goodness and fallenness-blood purchases a title to the land. Presence is not exile; suffering is not homelessness. Rather, the indispensability of one to the other places black subjectivity at the center of American identity. Even, and perhaps especially, in the place of abjection. The question would then remain: what would it mean to uproot and dismantle the structures that produce only wretched possibilities?

Fanon of course also participated in the 1956 conference, contributing his essay "Racism and Culture" to the proceedings and arguing for the total conception of racism-racism is not an 
affective disorder, he claims, but a complete cultural phenomenon whose eradication demands address on all levels. "Racism and Culture" is a largely programmatic essay and it can be read as a prelude to the more systematic, detailed elaborations of problems of national culture, political renewal, and the new humanism in Wretched of the Earth. As well, Fanon's contribution gathers into concise form many of his earlier considerations of the relation between revolutionary action, affective disorders, and conceptions of belonging in Black Skin, White Masks. But all of those considerations come back to the problem of time, and home never belongs to the present $o r$ the past for Fanon. Rather, there is only the future. The wretched possibilities and suffering under racist regimes and economies produce only the disjointure of time. Fanon writes:

Every human problem cries out to be considered on the basis of time, the ideal being that the present always serves to build the future.

And this future is not that of the cosmos, but very much the future of my century, my country, and my existence. In no way is it up to me to prepare for the world coming after me. I am resolutely a man of my time.

And that is my reason for living. The future must be a construction supported by man in the present. This future edifice is linked to the present insofar as I consider the present something to be overtaken. (Black Skin xvi-xvii)

The present is overtaken by the future, which is the victory of imagination of possibility over lived actuality. This is such an interesting temporality. The present offers so little, and yet the future must be thought on the basis of that present - the present as pure negation, rather than roots, titles to land, and the gift of home, however wretched and difficult. In this sense, Black Skin, White Masks is altogether programmatic, suggestive, and in some ways the product of an existential daydreamer. The present is wished away in flights of fancy, something that is nicely reflected in the rhetorical bookends of Black Skin, White Masks; the Introduction and Conclusion to the work read like prayers of exhortation, worry, and demand. Fanon frets over the obstinacy of the inferiority complex, yet sees in the emerging postcolonial moment an opening in the 
psyche, a break between the present and the imagination, and so, in a strange sort of recast of Zarathustra, the possibility of a resolute no spoken to the colonial condition in search of that yes Fanon says "resonates" from "cosmic harmonies." (Black Skin, xii) A beautiful daydream, for sure, and it is the dreamy character of a liberated imagination that gives Black Skin, White Masks its life and vibrant revolutionary character.

To what end, all of this dream and imagination? It is perhaps enough to say that Fanon wants the liberation of black people or even the colonized in general, for that is the answer we get in Wretched of the Earth. What does liberation entail? Wretched of the Earth offers a systematic study of institutional structures, their limitations, and necessary political transformations, but even that book ends with a dreamy notion of humanism uncoupled from the history of colonialism. Toward what does the new humanism point us? Fanon closes the Introduction to Black Skin, White Masks with an evocation of home:

As those of an Antillean, our observations and conclusions are valid only for the French Antilles - at least regarding the black man on his home territory. A study needs to be made to explain the differences between Antilleans and Africans. One day perhaps we shall conduct such a study. Perhaps it will no longer be necessary, in which case we can but have reason for applause. (Black Skin xviii)

We of course get just that study only a few years later with Fanon's 1955 essay, "West Indians and Africans," which contains its own reflections on home — albeit only implicitly—in terms of belonging, land, and the divergence of West Indian and African experiences of colonial domination. But here Fanon, as he restricts the claim of the book to the French Antilles, lays claim to a specific geography of experience. The validity of the observations and conclusionswhich is to say, the form of the argument and the logic of interconnection-issues from the connection and disconnection specific to the black Martiniquan subject. Imagination of a Martiniquan home, perhaps. Dream and imagination as the counter-narrative and productive of 
the counter-affects to shame - ecstasy, the joy of time with a future, and all forms of pleasure in friendship, and belonging.

Home territory is a difficult matter here. Recall that Fanon rejects Négritude precisely in terms of the location of home; he speaks for the French Antillean only, the one who is both Antillean and French, and so not an African who is ultimately lost in the Antilles and France. There is here a difference between the affect of shame in Fanon and the affect of mournful life in Négritude. In this sense, we can see even in Black Skin, White Masks the beginnings of Fanon's outright and uncomplicated rejection of nationalism. The implication of the Antilles in France and France in the Antilles produces all of the anxieties and pathologies of the colonized. And yet Fanon, in a manner similar to Baldwin, will at times identify this implication and reversible relation as home. Late in Black Skin, White Masks, Fanon writes:

What's all this about black people and a black nationality? I am French. I am interested in French culture, French civilization, and the French. We refuse to be treated as outsiders; we are well and truly part of French history and its drama ... I take a personal interest in the destiny of France, the French nation, and its values. What am I supposed to do with a black empire? (179)

This is a complicated passage. It comes near the close of the chapter on blackness and psychopathology, a chapter that details the vicissitudes of racial thinking. And in those multiple paths of race and strict racial identity, Fanon shows his rhetorical flexibility; the bleak and troubling account of blackness in a French context that begins the book-an account that diagnoses, then defends black subjectivity against the forceful imposition of French culturegives way to an evocation of mutual entanglement. Fanon shifts registers because he sees the consequences of rendering black subjectivity completely other in the colonial relation. There is no place for black nationalism—what he here calls a black empire —in Fanon's work because, for all of its brutality and cruelty, French is the language of the French Antillean. The problem is 
with the lack of recognition, which is of course the subject of the immediately following, final chapter in Black Skin, White Masks that explores how the failed struggle for recognition is a loss precisely because the subjects in relation are already entangled. We might say that the French language is home for Fanon, even if that home is alienating. Home as homelessness.

If we press Fanon closer to Baldwin in this moment, then we begin to see the complexity of theorizing the notion of home in the Americas. The Americas tell a terrifying history and produce a world with no words or comfort for black subjectivities. And yet black people survive and create; abjection has its limits and resistance is as much a part of the story of the Americas as suffering and violence. When Fanon and Baldwin turn to the question of home, it is noteworthy that they stay close to the affect of shame. The inferiority complex and the self-hatred it produces make home a precarious, complicated, even bloody affair, but it is nonetheless home. That connection to place, which is as much a connection through disconnection as anything else, is saturated with the sadness of memory and history of both the past and the present. But such a connection further motivates the question of the future: if this place is home, then what sort of revolutionary action is called for in the name of a liberation of a home that is already ours?

\section{Love and Humanism}

How can the American Negro's past be used? The unprecedented price demanded-and at this embattled hour of the world's history-is the transcendence of the realities of color, of nations, and of altars. (Baldwin, The Fire Next Time 103)

Fanon's early work struggles with the question of transformation. Indeed, the diagnostic sensibility of Black Skin, White Masks frames every question. Language is diagnosed as the problem of diction and the colonization of thought. Incarnation is diagnosed as the fate of black bodies under regimes of anti-black racism. History is diagnosed as the impossible-and 
ultimately unnecessary — burden of a degraded and degrading past for the black Americas. And so on. That said, Fanon is careful to not over-pathologize black people; no matter the neurotic conditions produced by colonialism and the anxieties of the emerging postcolonial moment, the black subject is always capable of struggle, defiance, and critical self-assertion.

Still, the terms of that critical self-assertion remain largely underdeveloped and present only in small, though important, gestures toward another future. The conclusion to Black Skin, White Masks raises significant issues of history and consciousness, arguing simply that the black subject only becomes fully a subject when he or she eschews historical experience and becomes, perhaps for the first time, in possession of consciousness as a question. This is a wholly speculative claim and poetic evocation; the conclusion reads like a prayer and plea, rather than a revolutionary theorizing of consciousness and its possibilities. We are left with very little sense of how transformation is possible. Under what worldly, existential conditions is the black subject possible? How is bad faith transformed into an authentic subject? What sorts of cultural and political structures make another subject possible? What is blackness after-and so not just in the wake of-colonialism?

In Wretched of the Earth, we get an answer in detail that has since become the core of so much postcolonial theory. Decolonization names the transformative process that moves the colonized toward the sorts of futures we see in the conclusion of Black Skin, White Masks: beginning again after history, the subject in question, imagining out from under the yoke of colonialism and its Manichean thinking. What feeling initiates decolonization?

Wretched of the Earth is structured around the affect of grievance. Grievance, in turn, is structured by memory. This is why key parts of Wretched of the Earth make careful distinction between the authentic, revolutionary grievance against colonialism and its lingering effects and 
the intra-African memory of the slave trade and all those companion theories of savagery, inferiority, and the shame of slavery. ${ }^{5}$ Memory of the internal slave trade survives in the embittered, sometimes cruel ethno-racial stereotypes of different regions of Africa, where the north is remembered as the greedy, cruel slave trading Arab and the sub-Saharan, black African is remembered as barbaric and submissive. Fanon eschews this memory in favor of the memory that mobilizes African solidarity: the memory of European domination. The former memory fractures solidarity and divides Africa against itself, but the latter remembers the decimation of colonialism no matter the region, ethnicity, or color. In that distinction, we see how the outrage of the past, the rage produced by the memory of foreign domination, transforms the presence of colonialism in everyday life and the psychological structures of a not-yet-decolonized postcolonial moment from alienating ghosts to what they should be for revolutionary action: occasions for rage and grievance. Affect at this moment moves Fanon away from the diagnostic of despair in the analyses of shame, toward the mobilization of cultural and political violence in the mood of rage and grievance.

How, then, is grievance related to the ultimate aim of Black Skin, White Masks and Wretched of the Earth: the articulation and evocation of the new humanism? The new humanism is Fanon's fantasy of a life after colonialism, the emergence of a sense of the human outside the Manichean logic of conquest and subjugation. Colonial logic splits the world in two, which in turn splits the post-colonial nation into mimicked structures of difference and absolute opposition. The memory of grievance identifies the source of that logic in two sites: the occupier's presence and the institutional and psychological structure of the colonial system. The latter survives political and economic presence. As we have seen, the presence of the colonial system in the internal life of the colonized subject generates the affective cluster shame, so we 
can see in grievance (inseparable as it is from rage) the counter affect-the revolutionary affect par excellence for Fanon-to alienation. And so we can see that grievance functions as a decolonizing force. Memory against colonial memories. The precondition of the new humanism, grievance clears the space for another kind of subjectivity to emerge in that it identifies, with the lucidity of revolutionary vision, the exact terms of transformation. The colonizer is named and, in acts of violence, targeted for resistance and overcoming. At this moment, we catch sight of Fanon's final temporality as grievance transforms the colonial past and post-colonial future with a new and radicalized memory, which harnessed in the present-Fanon's liberating present, rather than the alienated lifeworld colonized consciousness - as a revolutionary psychological, epistemological, and ontological force.

Grievance, then, accounts for revolutionary motivation. Motivation is a peculiar and crucial term in any action whatsoever, especially in the exceptionally high stakes of revolutionary cultural, political, and self-transformation. If grievance motivates action, then grievance is charged with sustaining both the possibility and the necessity of action. One is motivated when one sees a possible future, which in this case is the vision of subjectivity and intersubjectivity outside Manichean colonial logic and its grievances. Desire for the possible future is further motivated by a sense that the past—and the present it has come to form —is untenable, atrocious, and fundamentally morally outrageous. Thus, grievance has an ecstatic temporality marked by fracture and continuity at one and the same time. Grievance fractures time precisely because rage - that product of an authentically felt grievance-blocks the past from being folded into the future; pain, trauma, and the long shadow of suffering provoke outrage and rejection. And yet grievance, which keeps its intimate companion affect rage alive and is transformed by revolutionary consciousness, also keeps that long shadow alive by making 
the future out of a painful past and still morally outrageous present. The ecstasy of the revolutionary lies in this paradox. It goes by the name hope.

The lure, of course, is a new humanism. Fanon imagines the world without colonial categories and structures of thinking, an imaginary that someone like Paul Gilroy has taken to its logical conclusion in the repudiation of race and nationalist racial identities for theorizing a politics of justice. In Postcolonial Melancholia, Gilroy shows us how this repudiation is utopian in the very best sense - an imagination that puts the world of the present out of sorts with itselfwhile at the same time underscoring how the legacy of colonialism-Manichean thinkingsaturates the landscape of revolutionary politics with a certain melancholia. Melancholia, as per Freud's well-known definition, is the sadness and immobility of the psyche that results from the inability to locate the terms of psychic harm. One mourns when one names the object lost, then proceeds through various modes of working through loss, whether that be replacement, displacement, sublimation, or simple acceptance. Mourning knows the lost object. But melancholia suffers from what cannot, or perhaps just has not, been named. For Gilroy, drawing from Fanon's late work, categories of race and the Manichean structures they generate haunt revolutionary politics, and, so long as they go unnamed and operate as ghosts in the revolutionary machine, transformative politics are not transformative at all. Put in the terms of Wretched of the Earth, a new humanism is impossible without the transformation of the language of race as identity and roots (the language of Négritude) into the language of race as the basis for grievance, rage, and its motivation for revolutionary action.

It is here that we can catch sight of limits in Fanon's affective schema. The new humanism is by definition content-less. We cannot imagine the future in specific terms, precisely because it is the future. It is not yet here. All of our anticipations of what is to come are rooted in 
a not yet fully transformed past and present. Our vision of the future is therefore necessarily constrained by the relation between memory and imagination. I think that is the real strength of Fanon's notion of new humanism from its first evocation in Black Skin, White Masks to the final gestures in the conclusion to Wretched of the Earth. Fanon understands what it means to think the future as future. Affect is not content. That is, affect is in many ways akin to the atmosphere in a room, which one can name and describe without knowing the precise social, cultural, and political structures that will issue from or be formed by it. For example, one can describe the general affective structure of a piece of music - danceable, romantic, sexual, aggressive, sensual, and so on-without knowing what it will mean for the particularization of affects across a room when the DJ plays the song. A political song from the late-1960s Marvin Gaye might provoke fear and anxiety in a room of old conservative white people, sensuality and catharsis in a room of those in the know and solidarity, nostalgia for a generation, an eyeroll or two from a young crowd that knows the song only from infomercials, or just indifference from those unmoved by American soul music. Still, one can say something about the song itself and how it sets an atmosphere; affect has an atmospheric character as well as particular renderings (not always consistent in content) of that character in the particular embodied person. If one can say something, then perhaps one can begin to unfold an imagined unfolding of human relations in that atmosphere. Imagining, we might say, the results of imagination.

This is where Baldwin's long meditation on love becomes significant and central to any account of revolutionary politics. Fanon's account of revolutionary affect limits the imagination to the negative: we can imagine how we get to the point of imagining the new politics of a postcolonial humanism. What does that post-colonial humanism feel like? What is the atmosphere of the intra-human in the new humanism? The eroticism of Fanon's rage and grievance-the lure 
and seduction of being able to shed the pain of the past and present - needs the supplement of the imagination of the feeling after. Baldwin simply calls this love. He concludes The Fire Next Time with a famous evocation:

When I was very young, and was dealing with my buddies in those wine- and urinestained hall-ways, something in me wondered, What will happen to all that beauty? For black people, though I am aware that some of us, black and white, do not know it yet, are very beautiful ... [V]engeance, I wondered, when that vengeance was achieved, What will happen to all that beauty then? ... If we-and now I mean the relatively conscious whites and the relatively conscious blacks, who must, like lovers, insist on, or create, the consciousness of the others - do not falter in our duty now, we may be able, handful that we are, to end the racial nightmare, and achieve our country, and change the history of the world. (104-105)

Love and beauty. Baldwin's memory of the cruel, violent hallway also gives him a vision, however fleeting, of another future. A future in which beauty is sustained by love. Another kind of intersubjectivity, one that is perhaps unimaginable in the present, but one we must nevertheless make ourselves imagine. After so much violence, love is impossible. Yet, if grievance is to give way to a new humanism, if the Manichean logic of colonialism and its melancholic effect on the present is to die for the sake of another future, then the future must be imagined otherwise. Why not love? Love is the unimaginable, in so many ways. Who could imagine Baldwin's notion here, that black people and white people in the Americas could be lovers — with all the generosity and gratuitousness the word love suggests? We can only imagine this if humanism means something different. That is, we can only imagine love as the postrevolutionary affect when humanism is new.

What, then, are we to make of this weaving and unweaving relation between Baldwin and Fanon? In part, as we have seen, it is a question of thinking memory without atavism. Baldwin's distance from any variety of iterations of black nationalism - whether the metaphysical account 
of spirit and civilization in Négritude or the sometimes crass politics of the Nation of Islamchanges the language of remembering, and so the conceptual schemes by which we might imagine a future. Fanon and Baldwin are in the same conceptual space here: the new is what makes humanism possible for the future. From grievance to love, the colonial affect of shame becomes — or will become — a bad memory and sad history.

And yet Fanon leaves Martinique for Algeria. In so doing, Fanon moves from a diagnosis of the Martiniquan situation in the early work to the more general account of the colonized as such - a global notion, really - in the final reflections of Wretched of the Earth. Baldwin, no matter his exilic travel routes, always remains located in the United States. Harlem begins and ends his intellectual work.

I wonder what it would mean to claim Fanon back for the Americas. Such a claim would also require us to imagine Fanon without France and therefore simply as an American — simply of the Americas. In his reflections on home, Fanon repudiates any and all pretensions to a "black empire" in the name of the content-less, dream-laden future of a new humanism. Baldwin reminds us that it is possible to dream a new humanism and to de-link the imagination from the sort of total abjection of history we find in Fanon. Indeed, Baldwin reminds us that the imagination has never been fully bound by that abject history. This nuance on the affective transmission of history's pain reclaims more broadly the experience of the Americas, while, perhaps most importantly, also creating a space within which to think the experience of antiblack racism and home. It is worthwhile to recall a remark Baldwin makes in "Encounter on the Seine," an early essay in which he takes account of important difference between AfricanAmericans and Africans (anticipating so many of the observations made by Fanon in "West Indians and Africans"). Baldwin writes: 
The American Negro cannot explain to the African what surely seems in himself to be a want of manliness, of racial pride, a maudlin ability to forgive. It is difficult to make clear that he is not seeking to forfeit his birthright as a black man, but that, on the contrary, it is precisely this birthright which he is struggling to recognize and make articulate. Perhaps it now occurs to him that in this need to establish himself in relation to his past he is most American, that this depthless alienation from oneself and one's people is, in sum, the American experience. ("Encounter on the Seine" 39)

As Baldwin addresses himself to the hypothetical African, we see becoming-black and becoming-subject - "struggling to recognize and make articulate" - to be the very form of subjectivity itself. But this is an American subjectivity brought to a certain becoming because of the strangeness of history, made all the more strange, then also unprecedented, by the conditions of arrival and survival for black Americans. Depthless alienation is at once the condition of Americaness as such and the particular struggle for black Americans in a place that does not welcome or recognize, but only makes abject and subjugates.

In this intersecting moment of Fanon and Baldwin-for Fanon's diagnosis of the condition of the Americas is near exactly the same - the divergence that follows can be seen in the cluster of affects that gather to the site of alienation. Fanon and Baldwin cast history as a manifold of pain, suffering, subjugation, and trans-generational trauma, all of which set up in the psyche the affective structure of the inferiority complex. Language, thought, and embodiment all bear the marks of this complex. Memory and history connect the psyche to the past. The interval toward the future, however, marks that alternative affective structure, one in which Fanon's wresting free of memory and history — his Sartreanism brought to affective black subjectivitymakes hope possible and the imagination of another humanism inspires and motivates, even as a largely content-less idea. Hope does not need content; perhaps this relation and desire is more indebted to the pain of history than Fanon acknowledges. Baldwin's interval works from the pain of history in the development of a counter-narrative whose story resists the characterization of 
African-American history as complete abjection. African-American humanity, Baldwin writes in "Everybody's Protest Novel," "is our burden, our life; we need not battle for it; we need only to do what is infinitely more difficult — that is, accept it" (33). In this sense, we, through Baldwin, can read the interval between past and future in Fanon as a kind of theoretical protest novel, one that rejects life and, even (perhaps especially) in the most abject moments of history, denies "his beauty, dread, [and] power" (33).

If we read Fanon in that frame, then we can begin to see what it would mean to reclaim Fanon for the Americas and how that reclaiming alters the course of his abjection of memory, history, and affect. The key element of this reclaiming, I think, is the problem of language. Recall that Fanon gathers to Creole all the affects of abjection and colonial exclusion; in speaking Creole, the West Indian is an outsider in France and too ethnic in the Caribbean. While diction - that perfection of the French version of the French language-is no solution and only serves to deepen alienation, burying inferiority in the skin despite what consciousness and the tongue are capable of, it is noteworthy that Fanon never returns to Creole. And yet Creole is the language of the Americas, the vernacular that marks a place here, in this space, a marker that carries with it all that we want from a language: words for things, words for consciousness and its populations, and so words for the connection of self, world, and being. In a later essay, Baldwin makes this clear, while also underscoring the risk such marginal, wholly American languages undertake:

What joins all languages, and all men, is the necessity to confront life, in order, not inconceivably, to outwit death: The price for this is the acceptance, and achievement, of one's temporal identity ... It goes without saying, then, that language is also a political instrument, means, and proof of power. It is the most vivid and crucial key to identity: It reveals the private identity, and connects one with, or divorces one from, the larger, public, or communal identity. ("If Black English Isn’t a Language" 650) 
In some ways, this is just what Fanon meant when he wrote in the opening pages of Black Skin, White Masks that speaking a language is akin to taking on, then inhabiting, a world. However, Fanon does not see how the very language he assigns to abject history and the suffering present already opens a whole world, a world that cannot be thought apart from the pain of the pastCreole is a story of loss, even as it is a lexicon of the world - and yet still gives all of the texture and meaning of the world in this place, the Americas.

In the end, I wonder if this musing on affect, revolution, language, and place is not simply a gesture and attempt at articulating the very space Fanon wanted to take us in the closing line to "Racism and Culture": life after the colonial relation. For, in Fanon's work, that is the space of a subjectivity freed from the inferiority complex, which means, in the moment of twisting free, that all affects show up in new light. The body's sexuality becomes new, sadness and regret become new, mourning and hope become new-all of the newness Fanon anticipates is only anticipated because it is the future without a past. A future, perhaps, in which love is spoken in vernacular: a language in which it is already spoken, if not yet heard. A hearing tocome.

\section{Notes}

${ }^{1}$ See for example Martin Heidegger, Being and Time, section 29, which elaborates the there of Dasein in terms of state-of-mind.

${ }^{2}$ Louis Althusser, "Ideology and Ideological State Apparatuses," in Lenin and Philosophy.

${ }^{3}$ Tommie Shelby's work on community nationalism in We Who Are Dark is helpful here. Even though Shelby is critical of the ultimate scope of such nationalism, seeing important limits in the political strategy, his treatment of black power and its promise can be nicely mapped on to this reading of Baldwin.

${ }^{4}$ See Donna V. Jones's fantastic book The Racial Discourses of Life Philosophy, which demonstrates the deep and abiding debt the foundational figures of Négritude owe to the life 
philosophy of various European thinkers - in particular, Henri Bergson, Teilhard de Chardin, and Friedrich Nietzsche, as well as the (often racist) anthropological work of the late-nineteenth century in Africa.

${ }^{5}$ For a detailed account of the function of grievance in Fanon's Wretched of the Earth, see my "Fanon's Two Memories." I argue there that Fanon works with two memories, one of which he retains as necessary for revolutionary consciousness (grievance against colonialism), the other suppressed as necessary for the same (grievance against internal slave trade in Africa), but never justifies the distinction. This double-handed gesture undercuts the project of Wretched of the Earth for a handful of reasons, the most prominent being the occlusion of memory's anarchic power to form and deform political consciousness.

\section{Works Cited}

Althusser, Louis. "Ideology and Ideological State Apparatuses." Lenin and Philosophy. New York: Monthly Review Press, 2001. 127-86.

Baldwin, James. "Encounter on the Seine: Black Meets Brown." The Price of the Ticket. New York: St. Martin's Press, 1985. 35-40.

1985. 27-34.

. "Everybody's Protest Novel." The Price of the Ticket. New York: St. Martin's Press,

- "If Black English Isn't a Language, Then Tell Me, What Is?" The Price of the Ticket. New York: St. Martin's Press, 1985. 649-652.

—. "Princes and Powers." The Price of the Ticket. New York: St. Martin's Press, 1985, 5164.

. The Fire Next Time. New York: Vintage, 2004.

Drabinski, John E. “Fanon's Two Memories.” Forthcoming in South Atlantic Quarterly 112, no. 1 (2013).

Fanon, Frantz. Black Skin, White Masks. Trans. Richard Philcox. New York: Grove Press, 2008.

—. "Racism and Culture," in Toward the African Revolution. Trans. Haakon Chavalier and François Maspero. New York: Grove Press, 1994. 29-44.

—. "The "North African Syndrome," in Toward the African Revolution. Trans. Haakon Chavalier and François Maspero. New York: Grove Press, 1994. 3-16. 
- "West Indians and Africans," in Toward the African Revolution. Trans. Haakon Chavalier and François Maspero. New York: Grove Press, 1994. 17-28.

- Wretched of the Earth. Trans. Richard Philcox. New York: Grove Press, 2004.

Heidegger, Martin. Being and Time. Trans. John Macquarrie and Edward Robinson. New York: Harper \& Row, 1962.

Jones, Donna V. The Racial Discourses of Life Philosophy. New York: Columbia University Press, 2010.

Shelby, Tommie. We Who Are Dark. Cambridge: Harvard University Press, 2003. 